\title{
A Framework Within Which To Determine How We Should Use Animals In Science Education
}

\author{
Michael J Reiss \\ UCL Institute of Education, London, UK \\ 20 Bedford Way, London WC1H OAL, UK \\ m.reiss@ucl.ac.uk
}

\begin{abstract}
The scope of science is fundamentally to understand the natural (i.e., material, as opposed to aesthetic, moral, imaginary or other) domain. Since one of the more remarkable features of the Earth is the presence of millions of species of organisms, nearly 90 percent of them animals, one might imagine that animals would play a central role in school science education. But this is not the case. Biology curricula are heavily weighted towards humans, and inside and outside of school many students are now exposed to only a few non-human animal species. Here, I seek to provide a coherent framework within which we can consider how animals should be used in science education. To do this, I examine two main issues: (i) the purposes of science education, and (ii) an ethical analysis of how humans should use animals.
\end{abstract}

Keywords: biology curricula, use of animals, dissection, bioethics, animal rights 
One of the more remarkable features of the Earth is that it supports millions of different species of organisms, the great majority of which are animals, including an amazing number of insects! Accordingly, one might imagine that non-human animals would play a central role in school science education. But this seems not to be the case, even though a rigorous survey of biology curricula worldwide has yet to be undertaken. Rather, biology curricula are weighted heavily towards humans. There are a number of reasons for this, including health and safety concerns, the fact that many teachers of biology have little experience of ecology or whole organisms, a pressure on resources including technician time, and the influence from animal charities. But one of the more important reasons why animals are not included much in curricula is uncertainty within the science education community about how animals might most appropriately be used in school science.

Here, I seek to provide a coherent framework within which to consider how animals should be used in science education, examining two main issues: the purposes of science education, and an ethical analysis of how humans should use animals. My contention is that unless these two major issues are addressed, arguments about how we should use animals in science education lack a solid foundation. My focus is K-12, but the principles explored in this chapter also apply to pre- and post-school education.

\section{The purposes of science education}

The purposes of science education can be thought of as a subset of the purposes of education (Reiss and White 2014). What therefore might be the purposes or aims of education? Some philosophers of education have argued that education would do well to have no aims. Paul Standish (1999) was exercised by what he saw as a 'grammatical oddness' here: asking what the aims of education are is like asking about the aims of a city. There is not much sense, he argued, in asking 'What are the aims of Aberdeen?'

Despite this argument, it is difficult to defend the notion that education should be aimless. People do design school curricula, run schools and decide how to train teachers with purposes in mind. And if we look at things historically, we can see even from a cursory survey that education has been credited with diverse aims over the years. Nevertheless, two broad groupings can be discerned. First, those where the intention is to develop the individual for her/his own benefit; and second, those where the intention is to develop individuals so that they may collectively contribute to making the world a better place (Reiss 2007). These two groupings are typical of much social policy in many countries. So, for example, in the west, under-age pregnancy, illicit drug use and speeding in cars are generally seen as bad both for the individuals concerned (loss of opportunities, mental and physical harm, risk of injury or death) and for the rest of society (financial cost, more burglaries, harm and upset caused to families and friends).

John White and I have argued that there are two fundamental aims of school education: namely, to enable each learner to lead a life that is personally flourishing and to help others to do so too (Reiss and White 2013).

What constitutes a flourishing life? 
The notion that humans should lead flourishing lives is among the oldest of ethical principles, one that is emphasised particularly by Aristotle in his Nicomachean Ethics and Politics. There are many accounts as to what precisely constitutes a flourishing life. A hedonist sees it in terms of maximising pleasurable feelings and minimising painful ones. More everyday perspectives may tie it to wealth, fame, consumption or, more generally, satisfying one's major desires, whatever these may be. Admittedly, there are difficulties with all these accounts (White 2011). A problem besetting desire satisfaction is that it allows ways of life that virtually all of us would deny were flourishing, a life wholly devoted to spread betting, for instance.

A life filled with whole-hearted and successful involvement in more worthwhile pursuits - such things as significant relationships, meaningful work, other activities one enjoys doing - is on a different plane. Virtually all of us would rate it fulfilling. A central aim of the school should therefore be to prepare students for a life of whole-hearted and successful engagement in worthwhile relationships, activities and experiences that they have not had foisted upon them. This aim also involves acquainting students with a wide range of possible options from which to choose. With their development towards increasingly autonomous adulthood in mind, schools should provide students with increasing opportunities to choose among the pursuits that best suit them. Young children are likely to need greater guidance from their teachers, just as they do from their parents. Part of the function of schooling, and indeed parenting, is to prepare children for the time when they will need to, and be able to, make decisions more independently.

\section{Equipping every student to help others to lead personally fulfilling lives}

We want students to want other people, as well as themselves, to lead fulfilling lives. Negatively, this means not hurting them, not lying to them, not breaking one's word or in other ways impeding them in this. Positively, it means helping them to reach their goals, respecting their capacity to make informed choices and being fair, friendly and cooperative in one's dealings with them. Schools can reinforce and extend what parents and others in families do in developing morality in children. Schools can widen students' moral sensitivity beyond the domestic circle to those in other communities, locally, nationally and globally. They can also help students to think about moral conflicts in their own lives and in the wider spheres just mentioned. They can encourage students to reflect on the basis of morality, including whether this is religious or non-religious.

As part of their moral education, schools should help students to become informed and active citizens. Dispositionally, this means encouraging them to take an interest in political affairs at local, national and global levels from the standpoint of a concern for the general good; and to do this with due regard to framework values of liberal democracy such as freedom, individual autonomy, equal consideration and cooperation. Young people also need to possess whatever sorts of understanding these dispositions entail, e.g., an understanding of the nature of liberal democracy in general, of divergences of opinion about it, and of its application to the circumstances of their own society.

As future citizens, the great majority of students will contribute to the general wellbeing, as well as to their own, through work. This will often be remunerated, though much of it, e.g., caring for children or elderly relatives, may not be. As rational beings, students will eventually have to make choices about what kind of 
work to engage in. Schools should be helping them in this by making them aware of a wide range of vocational possibilities and routes into them, as well as their advantages and disadvantages.

\section{The possible aims of school science education}

There are a multiplicity of aims for school science education (Reiss 2007) though these are often implicit. A frequent aim of many science courses has been for them to provide a preparatory education for the small proportion of individuals who will become future scientists (in the commonly understood sense as employed professionals). This aim has been widely critiqued on democratic grounds (e.g., Millar and Osborne 1998). After all, what of the great majority of school students who will not become such scientists?

Another aim is to enable 'scientific literacy'. Although there has been a longrunning debate as to the meaning of the term, generally scientific literacy is seen as a vehicle to help tomorrow's adults to understand scientific issues (Gräber and Bolte 1997). The basic notion is that science education should aim to enhance understanding of key ideas about the nature and practice of science as well as some of the central conclusions reached by science. Perhaps to be included within this category is the argument that to be an educated person in the $21^{\text {st }}$ Century is to understand something of science (e.g., Shamos 1995). This is the 'science as culture' argument; that science is as worth studying in itself, as are, for example, literature and the arts.

A further aim is that many science courses hope that as a result of what is learnt, students both now and in the future, as adults, will be able to gain practical benefit from it. At its most straightforward this might be by entering paid employment that draws on what they have learnt in science. Although, as noted above, most students do not enter such careers, they too may still benefit individually from their school science. For example, in most science courses, in countries round the world, it has long been accepted that one of the justifications for the inclusion of certain topics is that knowledge and understanding of them can promote human health. Such topics may include infectious diseases, diet, reproduction and contraception, exercise and the use of drugs (including smoking and alcohol).

Another argument that science education should be for public understanding (American Association for the Advancement of Science 1990). Somewhat related to this is the view that school science education should facilitate democracy. John Longbottom and Philip Butler (1999) argue that:

If citizens have some knowledge of the natural world and of the process of gaining that knowledge, then they may be empowered to view critically the social world. Citizens who are critically minded, and who can analyze and challenge social structures, will be better able to implement democratic ideals. In this way, science education, in combination with a general education that teaches democratic ideals, can play a valuable part in equipping citizens with knowledge for action.

The argument that school science education should promote democracy is related to the argument that it should be for citizenship (Jenkins 1999). In both cases there is 
what has been termed a 'weak version' and a 'strong version' (Reiss 2007). The weak versions consist of learning about what a democracy is and what it is to be a citizen. The strong versions entail using such knowledge in action to bring about change. These strong versions are closely allied to claims that the aim of school science education should be to effect social justice, ecological justice or socio-political action.

For example, Angela Calabrese Barton has worked with homeless children in the USA to develop more appropriate science learning. She has shown that active participation in science lessons, and real learning about science, take place when children believe that their work can bring about improvements for themselves, their friends and their families (Calabrese Barton 2001). She draws on feminist approaches to show that many of the students with whom she and her colleagues worked, whilst seen in school as not doing well in science, were actually perfectly capable of high quality science work provided they were given real choice in the science they worked at.

It is evident that there are currently diverse aims for school science education. It is important, though, to emphasise that most teaching of school science proceeds on the assumption that such knowledge is good for students, without the precise aims having been thought through with any rigour and without the science curriculum beginning from such aims. Instead, science curricula generally begin with science. It might be thought that this is a sensible starting point but it leads all too often to disengagement (Schreiner 2006) as many students fail to understand the point of what they are learning (Reiss 2000). Hence, the argument for starting with the overall aims of education and then seeing, within these, what science might contribute.

It is clear that school science can indeed contribute to human flourishing. The amount of science and type of school science in the curriculum that is necessary for human flourishing is another matter (Reiss and White 2014). So far as I am aware, the school curricula of all countries have science as a mandatory, core subject to be taught, typically, from the start of schooling (e.g., 5 or 6 years of age) up to the end of compulsory schooling (e.g., 15 or 16 years of age). Whilst what precisely is included within 'science' varies a bit from country to country, and while it isn't always called 'science' for younger pupils, the presence of school science is nearly always accepted as a given.

Furthermore, what gets included within the school science curriculum is typically determined mainly by curriculum history - i.e., what has previously been included - and by occasional battles; for instance, in England and Wales, about the extent to which the earth sciences should be included within science, within geography, or omitted from the school curriculum.

The analysis presented so far is human-focused; education is presumed to enable humans to flourish. This is not, of course, to ignore animals, plants or even inanimate objects - after all, your and my flourishing may be enhanced by the wellbeing of any companion animals we have; indeed, if either of us gets upset at the poor treatment of animals we consume for food, at the extinction of wild species or at more general damage to the environment, an argument centering on human flourishing can still lead to a great deal of concern being expressed and action being taken in defense of animals, plants and the environment more generally.

The broader question is whether we (humans) have any duties to non-humans for reasons that are not to do with human flourishing. This is one of the issues that I address in the next section, on how we should use animals. 


\section{How should humans use animals?}

Although it may be tempting to dive straight in and attempt to answer the question 'How should humans use animals?', the question is an ethical question and therefore consideration of how, in general, ethical questions can be answered is needed first. Otherwise one may simply end up in a classroom, as many teachers of school biology know from experience, with one group of students maintaining that it's fine to eat animals and use them in medical experiments while another group passionately disagrees - and neither group is helped by their teacher to provide arguments in support of their position.

Ethics is the branch of philosophy concerned with how we should decide what is morally wrong and what is morally right. We all have to make moral decisions daily on matters great or (more often) small about what is the right thing to do: Should I continue to talk to someone for their benefit or make my excuse and leave to do something else? Should I give money to animal charities or to medical charities? Should I give more weight to my interests than to those of others when choosing for whom to vote in an election?

We may give much thought, little thought or practically no thought at all to such questions. Ethics, though, is a specific discipline that tries to probe the reasoning behind our moral life, particularly by critically examining and analyzing the thinking which is or could be used to justify our moral choices and actions in particular situations (Reiss 2002).

\section{The way ethics is done}

Ethics is a branch of knowledge just as other intellectual disciplines, such as science, mathematics and history. Ethical thinking is not wholly distinct from thinking in other disciplines but it cannot simply be reduced to them. In particular, ethical conclusions cannot be unambiguously proved in the way that mathematical theorems can.

However, this does not mean that all ethical conclusions are equally valid. Some ethical conclusions - as in science - are more likely to be valid than others. It is a common fault in ethics courses to assert that there are no rights or wrongs in ethics.

One can be most confident about the validity and worth of an ethical conclusion if three criteria are met (Reiss 1999a). First, if the arguments that lead to the particular conclusion are convincingly supported by reason. Second, if the arguments are conducted within a well established ethical framework. Thirdly, if a reasonable degree of consensus exists about the validity of the conclusions, arising from a process of genuine debate.

It might be supposed that reason alone is sufficient for one to be confident about an ethical conclusion. However, there are problems in relying on reason alone when thinking ethically. In particular, there still does not exist a single universally accepted framework within which ethical questions can be decided by reason (Parfit 2011). Indeed, it is unlikely that such a single universally accepted framework will exist in the foreseeable future, if ever. This is not to say that reason is unnecessary but to acknowledge that reason alone is insufficient. For instance, reason cannot decide between an ethical system which looks only at the consequences of actions and one which considers whether certain actions are right or wrong in themselves, whatever their consequences. Then feminists and others have cautioned against too great an emphasis upon reason. Much of ethics still boils done to views about right and wrong 
informed more about what seems 'reasonable' than what follows from formal reasoning.

The insufficiency of reason is a strong argument for conducting debates within well established ethical frameworks, when this is possible. Traditionally, the ethical frameworks most widely accepted in most cultures arose within systems of religious belief. Consider, for example, the questions "Is it wrong to lie? If so, why?". There was a time when the majority of people in many countries would have accepted the answer "Yes, because scripture forbids it". Nowadays, though, not everyone accepts scripture(s) as a source of authority. Another problem, of particular relevance for school science, is that while the various scriptures of the world's religions have a great deal to say about such issues as theft, killing people and sexual behaviour, they say rather less that can directly be applied to the debates that surround many of today's ethical issues in science, for example those involving modern biotechnology. A further issue is that we are more conscious nowadays that we live in multicultural or pluralist societies. Within most countries there is no longer a single shared set of moral values.

Nevertheless, there is still great value in taking seriously the various traditions - religious and otherwise - that have given rise to ethical conclusions. People do not live their lives in ethical isolation: they grow up within particular moral traditions. Even if we end up departing somewhat from the values we received from our families and those around us as we grew up, none of us derives our moral beliefs from first principles, ex nihilo, as it were.

Given, then, the difficulties in relying solely on either reason or any one particular ethical tradition, we are forced to consider the approach of consensus (Moreno 1995). It is true that consensus does not solve everything. After all, what does one do when consensus cannot be arrived at? Nor can one be certain that consensus always arrives at the right answer - a consensus once existed that women should not have the vote and that beating was good for children.

Nonetheless, there are good reasons both in principle and in practice in searching for consensus. Such a consensus should be based on reason and genuine debate and take into account long established practices of ethical reasoning. At the same time, it should be open to criticism, refutation and the possibility of change. Finally, consensus should not be equated with majority voting. Consideration needs to be given to the interests of minorities, particularly if they are especially affected by the outcomes, and to those - such as young children, the mentally infirm and nonhumans - unable to participate directly in the decision-making process. At the same time, it needs to be born in mind that while a consensus may eventually emerge there is an interim period when what is more important is simply to engage in valid debate in which the participants respect one another, so far as is possible (c.f. Martin 1999), and seek for truth through dialogue (Habermas 1983). School education has an important role to play here.

\section{Is it enough to look at consequences?}

The simplest approach to deciding whether an action would be right or wrong is to look at what its consequences would be. No one supposes that we can ignore the consequences of an action before deciding whether or not it is right. This is obvious when we try to consider, for example, whether imprisonment is the appropriate punishment for certain offences - e.g., robbery. We would need to look at the 
consequences of imprisonment, as opposed to alternative courses of action such as imposing a fine or requiring community service. Even when complete agreement exists about a moral question, consequences may still have been taken into account.

The deeper question then is not whether we need to take consequences into account when making ethical decisions but whether that is all that we need to do. Are there certain actions that are morally required - such as telling the truth - whatever their consequences? Are there other actions - such as betraying confidences - that are wrong whatever their consequences? This is about the most basic question that can be asked in ethics and it might be expected by anyone who is not an ethicist that agreement as to the answer would have arisen. However, this is not the case. There still exists genuine academic disagreement amongst moral philosophers as to whether or not one needs only to know about the consequences of an action to decide whether it is morally right or wrong.

Those who believe that consequences alone are sufficient to let one decide the rightness or otherwise of a course of action are called consequentialists. The most widespread form of consequentialism is known as utilitarianism. Utilitarianism begins with the assumption that most actions lead to pleasure (typically understood, at least for humans, as happiness) and/or displeasure. In a situation in which there are alternative courses of action, the desirable (i.e., right) action is the one that leads to the greatest net increase in pleasure (i.e., excess of pleasure over displeasure, where displeasure means the opposite of pleasure, i.e., harm).

Utilitarianism as a significant movement arose in Britain at the end of the eighteenth century with the work of Jeremy Bentham and John Stuart Mill. However, its roots are much earlier. In the fifth century BCE, Mo Tzu in China argued that all actions should be evaluated by their fruitfulness and that love should be allembracing.

Utilitarianism now exists in various forms. For example, preference utilitarians argue for a subjective understanding of pleasure in terms of an individual's own conception of his/her well-being. What all utilitarians hold in common is the rejection of the view that certain things are right or wrong in themselves, irrespective of their consequences. Consider, for example, the question as to whether or not we should tell the truth. A utilitarian would hesitate to provide an unqualified 'yes' as a universal answer. Utilitarians have no moral absolutes beyond the maximization of pleasure principle. Instead, it might be necessary for a utilitarian to look in some detail at particular cases and see in each of them whether telling the truth would indeed lead to the greatest net increase in pleasure.

There are at least two great strengths of utilitarianism. First, it provides a single ethical framework in which, in principle, any moral question may be answered. It doesn't matter whether we are talking about the legalization of cannabis, the age of sexual consent or the use of frogs in science fairs; a utilitarian perspective exists. Second, utilitarianism takes pleasure and happiness seriously. The general public may sometimes suspect that ethics is all about telling people what not to do. Utilitarians proclaim the positive message that people should simply do what maximizes the total amount of pleasure in the world.

However, there are difficulties with utilitarianism as the sole arbiter in ethical decision making. For one thing, an extreme form of utilitarianism in which every possible course of action would have consciously to be analyzed in terms of its countless consequences would quickly bring practically all human activity to a stop. Then there is the question as to how pleasure can be measured. For a start, is pleasure to be equated with well-being, the subjective experience of happiness or the fulfilment 
of choice? And, anyway, what are its units? How can we compare different types of pleasure, for example sexual and aesthetic? Then, is it always the case that two units of pleasure should outweigh one unit of displeasure? Suppose two people each need a single kidney. Should one person (with two kidneys) be killed so that two may live (each with one kidney)?

Utilitarians claim to provide answers to all such objections (e.g., Singer 1993). For example, rule-based utilitarianism accepts that the best course of action is often served by following certain rules - such as 'Tell the truth', for example. Then, a deeper analysis of the kidney example suggests that if society really did allow one person to be killed so that two others could live, many of us might spend so much of our time going around fearful that the sum total of human happiness would be less than if we outlawed such practices.

\section{Intrinsic rights and wrongs}

The major alternative to utilitarianism is a form of ethical thinking in which certain actions are considered right and others wrong in themselves, i.e., intrinsically, regardless of the consequences. Consider, for example, the question as to whether a society should introduce capital punishment. A utilitarian would decide whether or not capital punishment was morally right by attempting to quantify the effects it would have on the society. Large amounts of empirical data would probably need to be collected, comparing societies with capital punishment and those without it with regard to such things as crime rates, the level of fear experienced by people worried about crime and the use to which any money saved by the introduction of capital punishment might be put. On the other hand, someone could argue that regardless of the consequences of introducing capital punishment, it is simply wrong to take a person's life, whatever the circumstances. Equally, someone could argue that certain crimes, for example first degree murder, should result in the death penalty - that this simply is the right way to punish such a crime.

There are a number of possible intrinsic ethical principles and because these are normally concerned with rights and obligations of various kinds, this approach to ethics is often named 'deontological' (i.e., 'rights discourse'). Perhaps the most important such principles are thought to be those of autonomy and justice.

People act autonomously if they are able to make their own informed decisions and then put them into practice. At a common sense level, the principle of autonomy is why people need to have access to relevant information, for example before consenting to a medical procedure.

Autonomy is concerned with an individual's rights; justice is construed more broadly. Essentially, justice is about fair treatment and the fair distribution of resources or opportunities. Considerable disagreement exists about what precisely counts as fair treatment and a fair distribution of resources. For example, some people accept that an unequal distribution of certain resources (e.g., educational opportunities) may be fair provided certain other criteria are satisfied (e.g., the educational opportunities are purchased with money legally earned or inherited). At the other extreme, it can be argued that we should all be completely non egoistic or nepotistic.

Rights are accompanied by duties but the relationship between rights and duties is often misunderstood. It is typically supposed that if I have rights then I also have duties - as in the political slogan that rights need to be accompanied by 
responsibilities. To see the logical error in this, consider a newborn baby. If ever a creature had rights it is surely a newborn baby. It presumably has the right to be fed, kept warm, protected and loved. But what duties does it have? Surely none. A newborn baby is simply too young to have duties. It is not yet responsible for its actions. However, others have duties to it - namely to feed it, keep it warm, protect it and love it. Normally such duties are fulfilled by the child's parent(s) but if neither parent is able to undertake these duties, for whatever reason, the duties pass to others, for example other relatives, foster parents, adoptive parents or social services. In general, if A has a right, there is a B who has a duty to ensure that A's rights are met.

If it is the case that arguments about ethics should be conducted solely within a consequentialist framework, then the issues are considerably simplified. Deciding whether anything is right or wrong now reduces to a series of detailed, in depth studies of particular cases. Much energy can be wasted when utilitarians and deontologists argue. There is little common ground on which the argument can take place. The safest conclusion is that it is best to look both at the consequences of any proposed course of action and at any relevant intrinsic considerations before reaching an ethical conclusion.

\section{Virtue ethics}

A rather different approach to the whole issue of ethics is provided by virtue ethics. Instead of starting from particular actions and trying to decide whether they fail to maximise the amount of happiness in the world, are divinely forbidden or infringe someone's rights, virtue ethics focuses on the moral characteristics of good people. For example, think about a good teacher. What characteristics might we expect them to manifest? We might want them to know their subject, to treat all students fairly, to be able to maintain order in the classroom, to maximise students' chances of doing well in any examinations, to be able to communicate clearly, to have a sense of humour and so on. Some of these are skills - for example the ability to maintain order - but some are personality traits that we call virtues - notably treating all students fairly, rather than, for example, favouring males, Asians, high attaining students or those who are good at baseball.

Virtue ethics has an ancient pedigree - receiving considerable impetus from Aristotle - and has undergone something of a revival since the 1970s. Part of the reason for this may be connected with a somewhat instrumental tendency in much of the training of such professionals as doctors, nurses, lawyers, accountants and so on, in which the idea of moral goodness features little. And yet many people who have to deal with such professionals (as patients and clients) want them to manifest virtues as well as be knowledgeable and technically skilled.

\section{Widening the moral community}

Traditionally, ethics has concentrated mainly upon actions that take place between people at one point in time. In recent decades, however, moral philosophy has widened its scope in two important ways. First, intergenerational issues are recognised as being important (Cooper and Palmer 1995), and second, interspecific issues are now increasingly taken into account (e.g., Rachels 1991). 
Nowadays we are more aware of the possibility that our actions may affect not only those a long way away from us in space (e.g., pollutants produced in one country affecting another) but also those a long way away from us in time (e.g., increasing atmospheric carbon dioxide levels altering the climate for generations to come). Human nature being what it is, it is all too easy to forget the interests of those a long way away from ourselves. Accordingly, a conscious effort needs to be made so that we think about the consequences of our actions not only for those alive today and living near us, about whom it is easiest to be most concerned.

Interspecific issues are of obvious importance when considering our use of animals and ecological questions. Put at its starkest, is it sufficient only to consider humans or do other species need also to be taken into account? Consider, for example, the use of new practices (such as the use of growth promoters or embryo transfer) to increase the productivity of farm animals. Many people feel that the effects of such new practices on the farm animals themselves need to be considered as at least part of the ethical equation before reaching a conclusion. This is not, of course, to accept that the interests of non-humans are equal to those of humans. While a small proportion of people do argue that this is the case, many accept that while non-humans have interests these are generally less morally significant than those of humans.

Accepting that interspecific issues need to be considered leads one to ask 'How?' A standard utilitarian answer is that we should consider just the pleasures and pains that would result from any action but is this sufficient? For example, would it be right to produce, whether by conventional breeding or modern biotechnology, a breed of chicken unable to detect pain and unresponsive to other chickens? Such a breed would not be able to suffer and its use might well lead to significant productivity gains: it might, for example, be possible to keep it at very high stocking densities. Someone arguing that such a course of action would be wrong would not be able to argue thus on the grounds of animal suffering. Other criteria would have to be invoked. It might be argued that such a course of action would be disrespectful to chickens or that it would involve treating them only as means to human ends and not, even to a limited extent, as ends in themselves.

\section{The use of animals in science education: some examples}

Students come to their science lessons with all sorts of views about how animals, plants and the physical environment should be treated by humans (e.g., Lock and Millett 1992). There are many aspects to the questions of how science education should deal with animals. I will start with animal dissection (Lock and Reiss 1996) and then go on to consider the issue as to whether animals should be brought into or kept in schools. Finally, I consider the more general issue as to what we might hope, as educators, that students would gain from considering how humans should use animals, using some of the ethical tools described above.

\section{Dissection in schools}

Dissection is the act of cutting up a plant or dead animal in order to investigate its internal structures and, by careful anatomical exploration, to reveal its organs and tissues. The dissection of whole animals in schools has become less common than it once was, partly because of changing perceptions by many students and some biology 
teachers about whether dissection is right, in part because of campaigning by organizations such as Animal Aid, PETA and the Royal Society for the Protection of Animals.

The main arguments in favor of animal dissection, whether of whole organisms (e.g., rats, fish, frogs, earthworms, cockroaches) or parts of organisms killed for other purposes (e.g., sheep's hearts, sheep's kidneys, bull's eyes, pig's trotters, unfertilized hen's eggs, skeletal muscle), are that such dissection:

- Provides a knowledge of the internal structure of tissues, organs and whole organisms better than can be provided by alternatives (e.g., three-dimensional models, computer software, videos).

- Enables students to learn through active involvement.

- Helps students better to appreciate what certain careers might entail (e.g., medicine, veterinary medicine, animal technician).

The main arguments against animal dissection are that this:

- Involves the taking of life.

- Involves the rearing and killing of animals in circumstances that may cause suffering (e.g., physical and mental pain in battery chickens, boredom in laboratory rats).

- Lessens respect for life and so cheapens it.

- Offends some fellow students.

- Puts some students off biology.

Some of these arguments apply with less force when only parts of organisms killed for other purposes (e.g., for food) are used for dissection.

In a review of the science curriculum in England that was designed and undertaken by 16-19 year-olds, when 16-17 year-olds were asked 'Should students be given the choice to do dissection? [and the term will have been understood to refer to animals]', 86\% of 1469 questionnaire responses said 'Yes', 7\% said 'No' and 7\% expressed no opinion (Murray and Reiss 2005). A decade before this study, Lock and Reiss (1996) recommended that the following practices be followed if animal dissection is undertaken in schools:

- Each school should formulate its own policy on dissection and make it freely available to students and parents.

- Students should be told that dissection is not required by any of the Examining Boards in the UK.

- Students should be told, in advance, when dissection is to take place. 
- In advance of dissection, students should be encouraged to discuss the ethical implications of dissection in an atmosphere that allows them to develop their thinking without being afraid that their views will be ridiculed.

- Dissection of parts of organisms obtained for other purposes should, in most cases, be used in preference to the dissection of whole organisms.

- Alternative work must always be provided. Such work should, so far as is possible, be of the same intellectual worth and interest as the dissection.

- Dissection of any sort is inappropriate for children under the age of 11 .

Dissection of whole organisms should only be undertaken by students over the age of 16. Little is gained by a teacher demonstrating a dissection to a whole class unless this is to instruct students or students prior to their doing their own dissection.

\section{Animals in schools}

Animal dissection is not, of course, the only issue in respect of how animals should be used in schools. In many schools, animals are kept or brought into classrooms. In addition, students may be taken on visits to zoos or to field centers; more indirectly, students watch animals on film and consider them in such contexts as biodiversity, genetics and agriculture.

Some campaigning organizations have argued that animals should neither be kept in schools nor brought into them. There are two main reasons advanced for such a stance: first, that a school is unable to provide an environment in which animals can be kept well (even for short periods of time); second, that such actions are simply morally wrong. It is difficult to find the first reason wholly convincing for all schools. Schools can do as good a job of keeping animals as homes can - and few of us would outlaw the keeping of all companion animals on utilitarian / animal welfare grounds. The second reason can be held consistently, for example by arguing that animals have rights so that just as it is wrong for us to enslave people (even if they are kept well), so it is wrong to keep animals.

It seems evident that if schools do keep animals on the premises, they have a duty to ensure that they are well-looked after. It is harder to look after mammals and birds well than some other taxa. Schools should certainly consider carefully the arguments for and against keeping animals in schools, or allowing them to be brought in for educational purposes. More generally, schools should encourage students to discuss these matters, as I now go on to argue.

\section{What might student gain by considering how humans should use animals?}

I have my own views about the validity of the moral arguments outlined above in respect of dissection and the place of living animals in schools. However, educationally, it seems difficult to defend the notion that any one view should prevail when a range of views can rationally be held. Accordingly, I end by maintaining that students themselves should consider the use of animals by humans (ethical issues being a sub-set of sociocultural issues) (Reiss 1999b). There are a number of 
educational arguments in favor of students undertaking such considerations (Davis 1999).

First, such teaching might heighten the ethical sensitivity of students. For example, students who have never thought about whether certain breeds of dogs should have their tails removed ('docked') or whether there is a right age at which calves should be removed from their mothers might be encouraged to think about such issues. Such thinking can result in students becoming more aware and thus more sensitive. It is not unusual, as a result, to find students saying 'I hadn't thought of that before'.

Second, such teaching might increase the ethical knowledge of students. The arguments in favor of this aim are much the same as the arguments in favor of teaching any knowledge - in part that such knowledge is intrinsically worth possessing, in part that possession of such knowledge has useful consequences. For example, appropriate teaching about the issue of rights might help students to distinguish between legal and moral rights, to understand something of the connections between rights and duties and to be able to identify fallacies in arguments for or against the notion of animal rights. Consider, for example, the issue of whether we should be concerned, on welfare grounds, about fishing. Relevant considerations, in addition to moral philosophy, include the possibilities of pain detection by fish and fish consciousness. To understand these well requires some knowledge of animal behavior, of neurophysiology, of psychology and of epistemology. More generally, we might want students to know whether there are morally relevant differences between animals and most humans - including the capacity to imagine a future life for oneself and to keep the concerns of others in mind.

Thirdly, such teaching might improve the ethical judgment of students. As Michael Davis, writing about students at university, puts it:

The course might, that is, try to increase the likelihood that students who apply what they know about ethics to a decision they recognize as ethical will get the right answer. All university courses teach judgment of one sort of another. Most find that discussing how to apply general principles helps students to apply those principles better; many also find that giving students practice in applying them helps too. Cases are an opportunity to exercise judgement. The student who has had to decide how to resolve an ethics case is better equipped to decide a case of that kind than one who has never thought about the subject.

(Davis 1999, pp. 164-5)

Finally, and perhaps most ambitiously, such teaching of ethics might make students better people in the sense of making them more virtuous or otherwise more likely to implement normatively right choices. It might, for instance, result in students reflecting more on the possibilities open to them, leading them to be less pressured by the views of others and so resulting in improved animal welfare or conservation of endangered species.

\section{References}

American Association for the Advancement of Science. (1990). Science for all Americans: Project 2061. New York NJ: Oxford University Press. 
Calabrese Barton, A. (2001). Science education in urban settings: seeking new ways of praxis through critical ethnography. Journal of Research in Science Teaching, 38, 899-917. http://dx.doi.org/10.1002/tea.1038

Cooper, D. E., \& Palmer, J. A. (Eds.) (1995). Just environments: Intergenerational, international and interspecies issues. London: Routledge. http://dx.doi.org/10.4324/9780203984758

Davis, M. (1999). Ethics and the university. London: Routledge.

Gräber, W., \& Bolte, C. (Eds.) (1997). Scientific literacy: An international symposium IPN 154. Kiel: Institut für die Pädagogik der Naturwissenschaften an der Universitatät Kiel.

Habermas, J. (1983). Moralbewusstsein und Kommunikatives Handeln. Frankfurt am Main: Suhrkamp Verlag.

Jenkins, E. W. (1999). School science, citizenship and the public understanding of science. International Journal of Science Education, 21, 703-710. http://dx.doi.org/10.1080/095006999290363

Lock, R., \& Millett, K. (1992). Using animals in education and research - student experience, knowledge and implications for teaching in the National Science Curriculum. School Science Review, 74(266), 115-123.

Lock, R., \& Reiss, M. J. (1996). Moral and ethical issues. In M. J. Reiss (Ed.), Living biology in schools (pp. 109-120). London: Institute of Biology.

Longbottom, J. E., \& Butler, P. H. (1999). Why teach science? Setting rational goals for science education. Science Education, 83, 473-492. http://dx.doi.org/10.1002/(sici)1098-237x(199907)83:4<473::aid-sce5>3.0.co;2-z

Martin, P. A. (1999). Bioethics and the whole: pluralism, consensus, and the transmutation of bioethical methods into gold. Journal of Law, Medicine \& Ethics, 27, 316-327. http://dx.doi.org/10.1111/j.1748-720x.1999.tb01466.x

Millar, R., \& Osborne, J. (Eds.) (1998). Beyond 2000: Science education for the future. London: Nuffield Foundation.

Murray, I., \& Reiss, M. J. (2005). The student review of the science curriculum. School Science Review, 87(318), 83-93.

Parfit, D. (2011). On what matters: Volume 1. Oxford: Oxford University Press. http://dx.doi.org/10.1093/acprof:osobl/9780199572809.001.0001

Rachels, J. (1991). Created from animals: The moral implications of Darwinism. Oxford: Oxford University Press.

Reiss, M. (1999a). Bioethics. Journal of Commercial Biotechnology, 5, 287-293.

Reiss, M. J. (1999b). Teaching ethics in science, Studies in Science Education, 34, 115-140. http://dx.doi.org/10.1080/03057269908560151

Reiss, M. J. 2000. Understanding science lessons: Five years of science teaching. Buckingham: Open University Press.

Reiss, M. J. (2002). Introduction to ethics and bioethics. In J. A. Bryant, L. M. Baggott-Lavelle, \& J. M. Searle (Eds.), Bioethics for scientists (pp. 3-17). New York: Wiley Liss. http://dx.doi.org/10.1002/0470846593.ch1

Reiss, M. J. (2007). What should be the aim(s) of school science education? In D. Corrigan, J. Dillon, \& R. Gunstone (Eds), The re-emergence of values in science education (pp. 13-28). Rotterdam: Sense.

Reiss, M. J., \& White, J. (2013). An aims-based curriculum: The significance of human flourishing for schools. London: IOE Press.

Reiss, M. J., \& White, J. (2014). An aims-based curriculum illustrated by the teaching of science in schools. The Curriculum Journal, 25, 76-89.

http://dx.doi.org/10.1080/09585176.2013.874953 
Schreiner, C. (2006). Exploring a ROSE-Garden: Norwegian youth's orientations towards science - seen as signs of late modern identities. Oslo: Faculty of Education, University of Oslo.

Shamos, M. H. (1995). The myth of scientific literacy. New Brunswick: Rutgers University Press.

Singer, P. (1993). Practical ethics (2nd ed.). Cambridge: Cambridge University Press.

Standish, P. (1999). Education without aims? In R. Marples (Ed.), The aims of education (pp. 35-49). London: Routledge.

White, J. (2011). Exploring well-being in schools: A guide to making children's lives more fulfilling. London: Routledge. http://dx.doi.org/10.4324/9780203815540

Michael Reiss is Professor of Science Education at University College London and a Fellow of the Academy of Social Sciences. He was a member of the Farm Animal Welfare Council/Committee (2004-12), Director of Education at the Royal Society (2006-08), a member of the GM Science Review Panel (2002-04) and Specialist Advisor to the House of Lords Select Committee on Animals in Scientific Procedures (2001-02). 